\title{
ANALYSIS OF NUTRITION INFORMATION OF ATHLETES COMPETING IN INTERCOLLEGIATE WRESTLING TURKEY CHAMPIONSHIP ${ }^{(1)}$
}

\section{ÜNIVERSITELERARASI GÜREŞ TÜRKIYYE ŞAMPIYONASINDA YARIŞAN SPORCULARIN BESLENME BILGILERININ ANALIZI}

\author{
Hayrettin GÜMÜŞDA $\breve{G}^{1}$, Alpaslan KARTAL ${ }^{2}$, Erol BAYKAN \\ ${ }^{1-2-3}$ Yozgat Bozok University, School of Physical Education and Sports, Yozgat / Turkey
}

ORCID ID: 0000-0002-1616-86711 ${ }^{1}, 0000-0003-1567-62762^{2}, 0000-0002-7429-3446^{3}$

Öz: Amaç: Araștırma da çeșitli üniversitelerde aktif olarak güreș sporuyla ư̆raşan bayan ve erkek güresçilerin beslenme bilgi düzeylerini karșlastırmak, gelir düzeyi ve beslenme konusunda eğitim alıp almadı̆ğnnn gürescilerin beslenme bilgi düzeylerine etkisi incelenmistir. Arasturmaya 11 bayan 44 erkek olmak üzere aktif güres sporuyla uğrayan 55 kişi gönüllü olarak katılııısțr. Yöntem: Demografik özelliklerine ilişkin bulgular ile bunların yorumlarına yer verilmiștit. Verilerde kayıp gözeler bulunmaktadır. Bu değerler kayıp veri olduğundan cevapsız olarak değerlendirilmiştir. Araş̧trmaya göre; Gelir durumlarr ile değişkenler (besin maddeleri, tüm değişkenler) arasında ANOVA test istatistiği sonucuna göre Gelir durumları arasında fark bulunmamıştr. $\mathrm{H} 0$ hipotezi kabul edilmiștir (besin maddeleri için $\mathrm{F}=0,509$, $\mathrm{p}=0,604>0,05$ - tüm değişkenler için $\mathrm{F}=0,094 ; \mathrm{p}=0,910>0,05$ ). Gelir durumlan arasinda fark bulunmadı̆ğndan post hoc analizi yapılmamışstr. Diğer değiskenler (SIVI maddeler, yenileme, kilo kontrolü, gida takviyeleri) normal dağılmadı̆̌ndan Kruskal Wallis testi yapılmışțr. Yapılan test sonuclarna göre $p$ değerleri 0,05 ten büyük olduğundan gelir durumu ile sıvı maddeler, yenileme, kilo kontrolü, gida

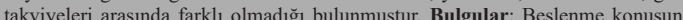

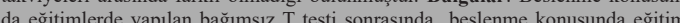
dia e bin

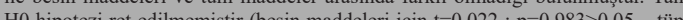

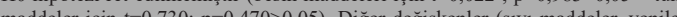
. me, kilo kontrolü, gida takviyeleri) normal dağılmadığgndan Mann Whitney U test yapılmıștrtr. Yapilan test sonuçlarına göre $\mathrm{p}$ değerleri $0,05^{\prime}$ ten büyük olduğundan beslenme eğitimi ile sıvı maddeler, yenileme, kilo kontrolü, gida takviyeleri arasında farklı olmadığı bulunmuştur. Kadın ve erkeklerin, karşsılaşırıası için yapılan bağımsız $\mathrm{T}$ testi sonrasında cinsiyet ile besin maddeleri ve tüm maddeler arasında farklı olduğu bulunmuștur. Yani H0 hipotezi ret edilmișțir (besin maddeleri için $\mathrm{t}=-2,198 ; \mathrm{p}=0,032<0,05$ - tüm maddeler için $\mathrm{t}=-2,294 ; \mathrm{p}=0,026<0,05)$. Ortalama değerlere bakıldığında erkekler kızlara göre daha fazla olduğu söylenebilir. Diğer değiskenler (sIVı maddeler, yenileme, kilo kontrolü, gida takviyeleri) normal dağılmadı̆̌̆ndan Mann Whitney U testi yapılmıștr. Yapılan test sonuçlarna göre p değerleri 0,05 ten büyük olduğundan cinsiyet ile sivı maddeler, yenileme, kilo

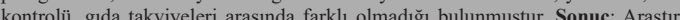

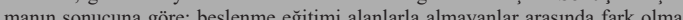
dı̆̆ı icin beslenme eğitimlerinin periyodik aralılklarla sporculara verilmesi uygun olabilir. Gelir durumunun beslenme bilgi düzeyi ile alakalı olmadı̆ğı anlaşılmıștrtr. Clabilir. Gelir durumunun bestenne bilgi düzeyi ile alakalı olmadığı anlassılmışur. yenileme, kilo kontrolü, gıda takviyeleri arasında fark olmadı̆ı̆ ortaya çıkmıştr.
Abstract: Aim: The study examined the nutritional information levels of female and male wrestlers actively engaged in wrestling at various universities, and the and male wrestlers actively engaged in wrestling at various universities, and the
effect of income level and nutrition education on the nutritional information levels of wrestlers. 55 people who experienced active wrestling, including 11 women and of wrestlers. 55 people who experienced active wrestling, including 11 women and
44 men, participated in the research as volunteers. Method: demographic char$44 \mathrm{men}$, participated in the research as volunteers. Method: demographic char-
acteristics of the findings and their interpretations are given. There are missing acteristics of the findings and their interpretations are given. There are missing
eyes in the data. These values have been evaluated as missed because they are lost data. According to the study, there was no difference between income states and variables (nutrients, all variables) according to the ANOVA test statistic. The HO hypothesis has been accepted ( $\mathrm{F}=0.509$ for nutrients; $\mathrm{p}=0.604>0.05-\mathrm{F}=0.094$ for all variables; $\mathrm{p}=0.910>0.05$ ). Post hoc analysis was not performed because there was no difference between income states. The Kruskal Wallis test was performed because other variables (liquids, replenishment, weight control, food supplements) were not normally distributed. According to the results of the test, $\mathrm{p}$ values are greater than 0.05 and it was found that there is no difference between income status and liquid substances, renewal, weight control and food supplements. Results: after the Independent $\mathrm{T}$ test conducted in nutrition education, it was found the bese

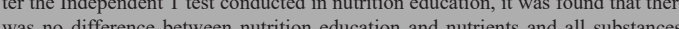

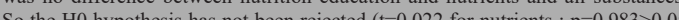
(l)

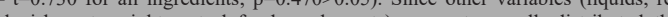
plenishment, weight control, food supplements) were not normally distributed, the Mann Whitney $U$ test was performed. According to the results of the test, $p$ values are greater than 0.05 and it was found that there was no difference between nutrition education and liquid substances, refreshment, weight control and food supplements. Women and men were found to be different between sex and nutrients and all ingredients after the Independent $t$ test for comparison. So the $\mathrm{H} 0$ hypothesi has been rejected $(t=-2.198$ for nutrients; $\mathrm{p}=0.032<0.05-\mathrm{t}-2.294$ for all ingredients $; p=0.026<0.05$ ). Men are more likely than girls when looking at average values. Since other variables (liquids, replenishment, weight control, food supplements) were not normally distributed, the Mann Whitney U test was performed. According to the results of the test, $\mathrm{p}$ values are greater than 0.05 and it was found the there was no difference betwe $p$ ser and liquid substances, renewal, weight con and food supplements. Conclusion: as there is no difference between those who and food supplements. Conch she as there is no dikerence between hose who be a

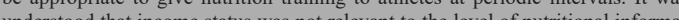
understood that income stats was not relevant to the level of nutritional information. It has been revealed that there is a difference between sex and nutrients and al ingredients, there is no difference between liquid ingredients, refreshment, weight control, food supplements.

Key Words: Wrestling, Nutrition, Competition, Analysis

Doi: 10.17363/SSTB.2020.34.3

(1) Sorumlu Yazar, Corresponding Author: Hayrettin GÜMÜŞDAĞ “Prof. Dr. Professor, Dr.”, Yozgat Bozok University, School of Physical Education and Sports, Yozgat / Turkey, hgumusdag06@hotmail.com, Geliş Tarihi / Received: 11.12.2019, Kabul Tarihi / Accepted: 13.03.2020, Makalenin Türü: Type of Article: (Araştırma-Uygulama; Research-Application) Çıkar Çatısması, Yok - Conflict of Interest, No, Etik Kurul Raporu veya Kurum İzin Bilgisi- Ethical Board Report or Institutiunal Approval, No 


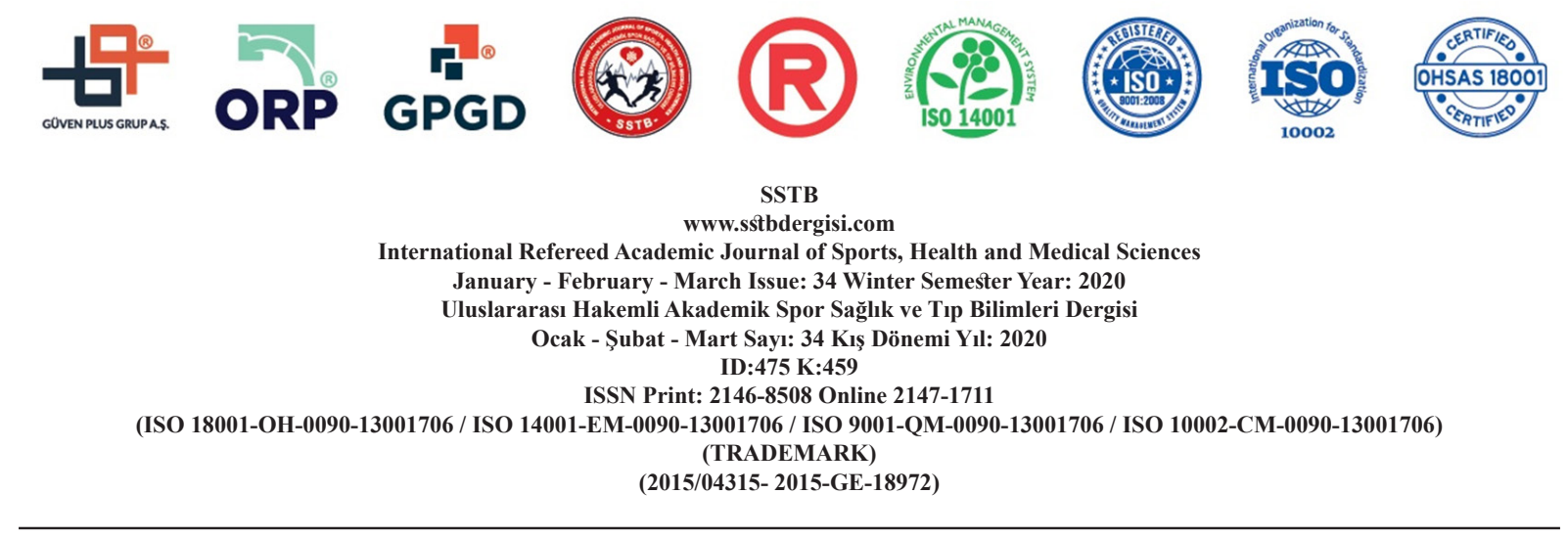

\section{INTRODUCTION}

Since nutrition in sports affects both the general health and the sporting performance of the athlete, it is now better understood that it is a subject to be focused on carefully and it has started to be focused on.

What is inevitable for every living thing is to ensure that physiological activities are carried out normally in the process from birth to death. It is seen that adequate and balanced nutrition also plays an important role in maintaining a healthy and high quality life of the individual. Our country has health problems in both developed and developing countries. The nutritional status of the people varies according to regions, seasons, socioeconomic level, rural-urban separation. One of the most important reasons for inadequate and unbalanced nutrition is lack of nutritional knowledge. Nutritional information is one of the factors affecting the nutritional status and habits of individuals, families and societies. Therefore, the place and importance of nutrition education in the protection and development of Health is great (Şanlıer, Konaklıoğlu, Güver, 2009).

Sports performance can be negatively affected by an unbalanced diet, as can be improved by a balanced diet. Athletes spend most of their time training in order to increase their efficiency, but also ignore the advantages that can be achieved with a good diet. Indeed, great efforts are made to train and proper nutrition is of great importance in order not to frustrate these efforts (Şemşek, 2001).

Nutrition: to meet the energy needs of the vital activities in our body, protect our health, physical growth and development to make it possible to practice and adapt your workout to maximize the effects of essential nutrients; carbohydrates, fats, proteins, vitamins, minerals and water can be defined as consuming a balanced diet (Bully, 2001). To know the feeding habits of adolescents and to determine their relationship with economic, socio-demographic factors and health are guiding in understanding the causes and consequences of eating habits (Tanrıverdi et al., 2011).

Athlete nutrition: according to the sex of the athlete, age, daily physical activities and the type of sport he does, training and competition periods by making arrangements for food intake in an adequate and balanced manner (Güneş, 2009). A good diet alone is not enough for a good yield. However, in a poor diet the yield level drops. In this respect, athletes should recognize their own food and their needs they should know (Sun and Ersoy.1997). In addition, the rate of injury in athletes is as high as $50 \%$ with good nutrition it is also stated that it can be reduced (Gülgün 2004). 


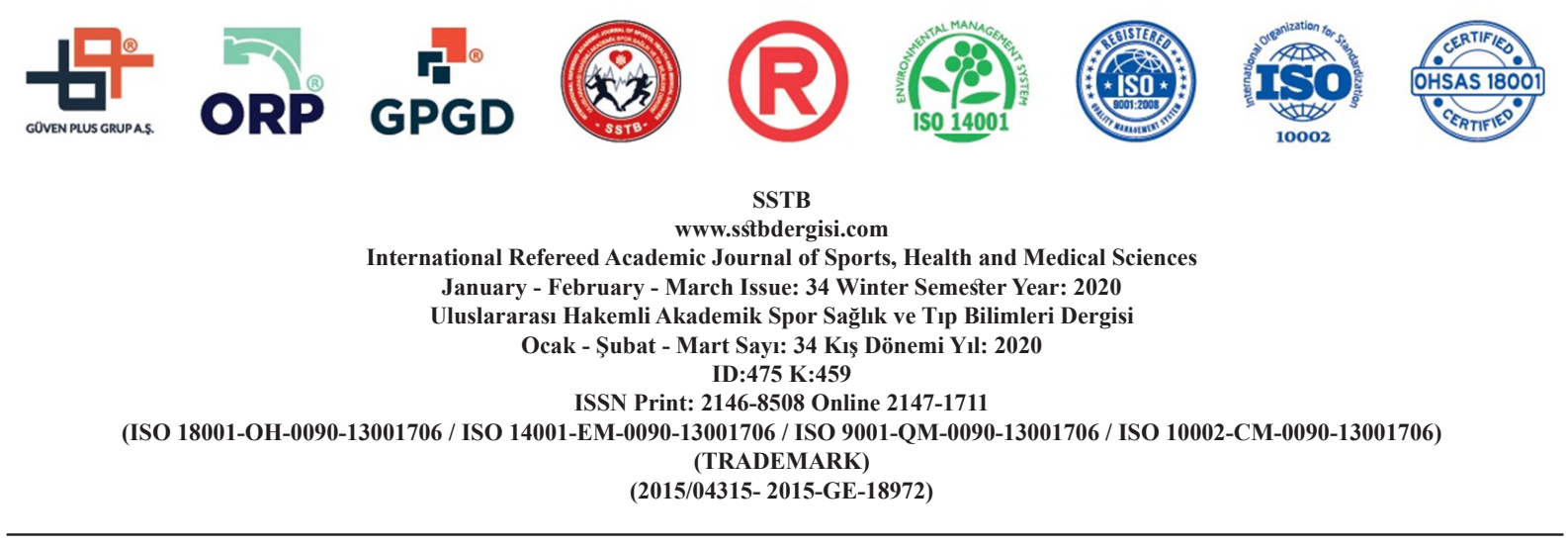

Wrestling: it is a fighting sport in which two people combine their body and intelligence to give each other the upper hand. It is the struggle of two wrestlers or people to establish superiority by using their technique, skill, strength and intelligence in accordance with the rules of "FILA" without using tools on certain sizes of mattresses (Şahin, 2005). Wrestling is a dual combat sport. Each wrestler tries to bring his opponent on his back or defeat him with points. It is not enough for him to have only good technique and condition, on the contrary, he must have the tactical ability to attack and defend in every case of wrestling with courage (Blacksmith, 1995 ). Wrestling is defined as the struggle of two wrestlers or people to establish superiority over each other by using their technique, skill, strength and intelligence in accordance with FILA rules without using a tool on a certain size cushion (Gökdemir, 2000). Turkish wrestling started its official structure with the establishment of the Republic in 1923;Turkish Wrestling Federation was established on 13 April 1923; it became a member of Fila and participated in the Olympics held in Paris in 1924 for the first time (Avcı oğlu, 1993).

Today, wrestling is important as a close combat sport, which requires the joint work of all body parts, as well as courage, reflex, skill, endurance and strength, which requires star- ting preparations at an early age (Kürkçü ve Özdağ, 2005).

\section{MATERIAL and METHOD}

\section{Research Group}

The sample of the study consisted of athletes who are currently actively engaged in the sport of wrestling, participating in the Intercollegiate Turkish Championship held on April 25-30, 2017 in Sivas province. There are 55 wrestlers in total, of which 11 are female students and 44 are male students.

\section{Data Collection Tools}

Measuring the nutritional information levels of the wrestlers participating in the survey a team of experts consisting of 6 sports dieticians, adapted to Turkish, administered the athlete nutrition information level determination questionnaire. Sports Nutrition Questionnaire (Zinn, schofield and wall, 2005) 23 substances were applied to participants in the Scale: 7 from nutrients, 5 from liquids, 5 from regeneration, 2 from weight gain, 2 from weight loss (4 under weight control) and 2 from food supplements. The correct answers given by the athletes are 1 , the wrong answers are -1 , and the undecided or not sure answers are 0 . IBM-SPSS 22.0 program has been entered. 


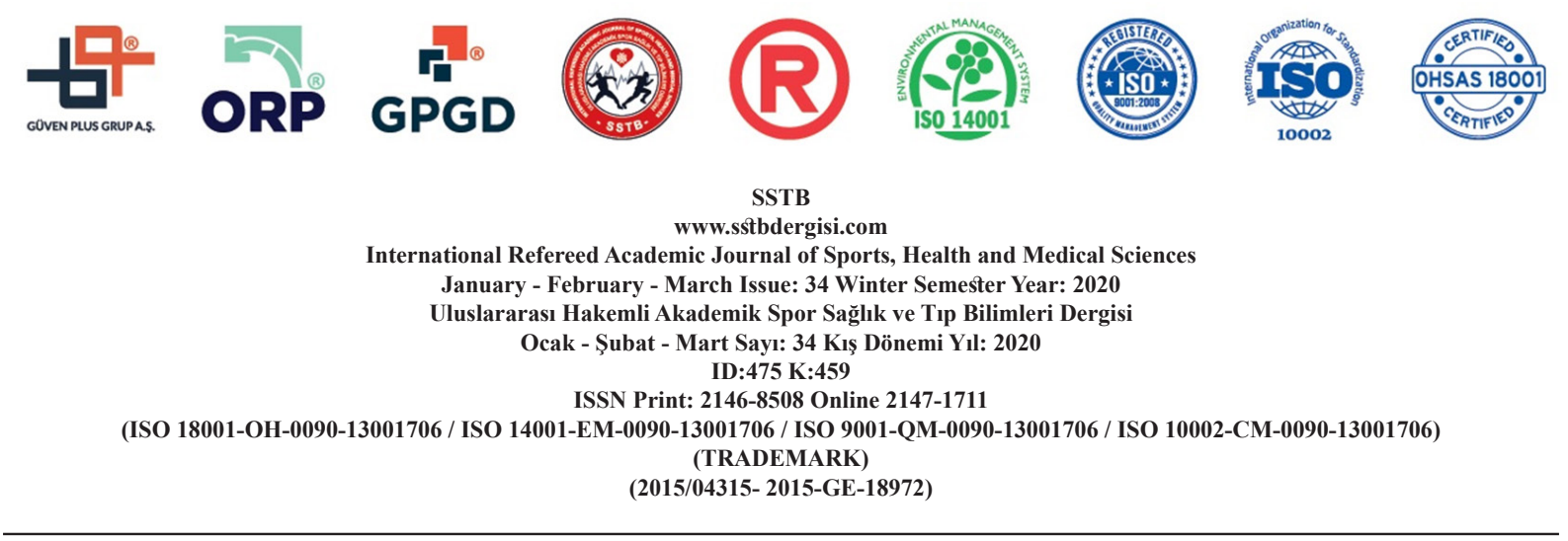

\section{Analysis of the Data}

During the data acquisition phase of the research, the athlete nutrition information level determination scale survey consisting of 23 items was applied to the athletes who participated in the inter-university wrestling championship held in Sivas province. In the statistical analysis, nutritional information levels were examined according to the variables of gender, income level and whether or not to receive training in nutrition. The IBM-SPSS 22.0 program was used to analyze the data and create the tables. In Analyses; by using descriptive statistical techniques, Kolmogorov-Smirnov test, it was determined whether or not the nutritional information score was normal distribution according to the variables. In cases where the normality assumption is provided, the Independent $\mathrm{T}$ test was used to compare two independent groups and the one-way variance analysis was used to compare more than two groups. The Mann Whitney $U$ test and Kruskal Wallis test analyses were used in groups three and above. The level of significance was evaluated as 0.05 .

\section{Hypotheses}

$\mathrm{H} 0$ : there is no difference between gender and variables (nutrients, liquids, replenishment, weight control, food supplements, all variables).
$\mathrm{H} 1$ : there is a difference between gender and variables (nutrients, liquids, replenishment, weight control, food supplements, all variables).

H0: there is no difference between income states and variables (nutrients, liquids, replenishment, weight control, food supplements, all variables).

$\mathrm{H} 1$ : there is a difference between income states and variables (nutrients, liquids, replenishment, weight control, food supplements, all variables).

H0: there is no difference between training and variables (nutrients, liquids, replenishment, weight control, food supplements, all variables).

$\mathrm{H} 1$ : there is a difference between training and variables (nutrients, liquids, replenishment, weight control, food supplements, all variables).

\section{FINDINGS}

Held at Taha Akgül Gymnasium in Sivas province on April 25-30, 2017 is still actively participating in intercollegiate gym championship in the sport of wrestling that they took the level of income of the people who made nutrition and nutrition education on nutrition knowledge level of male and female athletes and compare the effect of 6 dietitians to determine the level of knowledge and sports 
SSTB

www.sstbdergisi.com

International Refereed Academic Journal of Sports, Health and Medical Sciences

January - February - March Issue: 34 Winter Semester Year: 2020

Uluslararası Hakemli Akademik Spor Sağlık ve Tıp Bilimleri Dergisi

Ocak - Şubat - Mart Sayı: 34 Kış Dönemi Yıl: 2020

ID:475 K:459

ISSN Print: 2146-8508 Online 2147-1711

(ISO 18001-OH-0090-13001706 / ISO 14001-EM-0090-13001706 / ISO 9001-QM-0090-13001706 / ISO 10002-CM-0090-13001706) (TRADEMARK)

(2015/04315- 2015-GE-18972)

nutrition knowledge of athletes prepared by an expert team to determine the level of the scale adapted to Turkish was applied. Sports Nutrition Questionnaire (Zinn, schofield and wall, 2005).
In this section, the findings and interpretations of their demographics are given. There are missing eyes in the data. These values were evaluated as lost data and were not answered.

Table 1. Descriptive Statistics On Demographic Variables

\begin{tabular}{|c|c|c|c|}
\hline & & Number & $\%$ Percentage \\
\hline \multirow{2}{*}{ Gender } & Woman & 11 & 20,0 \\
\hline & Man & 44 & 80,0 \\
\hline \multirow{10}{*}{ Age } & 18 & 4 & 7,3 \\
\hline & 19 & 12 & 21,8 \\
\hline & 20 & 12 & 21,8 \\
\hline & 21 & 9 & 16,4 \\
\hline & 22 & 6 & 10,9 \\
\hline & 23 & 6 & 10,9 \\
\hline & 24 & 3 & 5,5 \\
\hline & 25 & 1 & 1,8 \\
\hline & 26 & 1 & 1,8 \\
\hline & 27 & 1 & 1,8 \\
\hline \multirow{5}{*}{ Income } & 2000 and Under & 16 & 29,1 \\
\hline & $2001-3000$ & 16 & 29,1 \\
\hline & $3001-4000$ & 10 & 18,2 \\
\hline & $4001-5000$ & 6 & 10,9 \\
\hline & 5001 and Over & 7 & 12,7 \\
\hline \multirow{2}{*}{ National Player } & Yes & 43 & 78,2 \\
\hline & No & 12 & 21,8 \\
\hline \multirow{2}{*}{$\begin{array}{l}\text { NUTRITION BEFORE } \\
\text { HAVE YOU TRAINED ABOUT? }\end{array}$} & Yes & 24 & 43,6 \\
\hline & No & 31 & 56,4 \\
\hline
\end{tabular}

As the table shows, of the 55 participants, 11 (20\%) were girls and $44(80 \%)$ were boys. Of the 55 respondents, $16(29.1 \%)$ were 2000 and below, 16 (29.1\%) were 2001-3000, 10 $(18.2 \%)$ were $3001-4000,6(10.9 \%)$ were 4001-5000, and 7 (12.7\%) were 5001 and 
International Refereed Academic Journal of Sports, Health and Medical Sciences

January - February - March Issue: 34 Winter Semester Year: 2020

Uluslararası Hakemli Akademik Spor Sağlık ve Tıp Bilimleri Dergisi Ocak - Şubat - Mart Sayı: 34 Kış Dönemi Yıl: 2020 ID:475 K:459

ISSN Print: 2146-8508 Online 2147-1711

(ISO 18001-OH-0090-13001706 / ISO 14001-EM-0090-13001706 / ISO 9001-QM-0090-13001706 / ISO 10002-CM-0090-13001706) (TRADEMARK)

(2015/04315- 2015-GE-18972)

over. According to the income situation, the largest group is those in the group 2000 and below and 2001-3000, while the smallest group is those in the group 5001 and above. All of the participants are wrestlers. Of the participants, 43 people (78.2\%) were national athletes and 12 people $(21.8 \%)$ were not national athletes. 24 people $(43.6 \%)$ of the athletes had previously been trained in nutrition. 31 people $(56.4 \%)$ declared that they had not been trained in nutrition before.

If a test scale measures the desired property correctly and without mixing it with other properties, this test is said to be valid. Reliability affects the validity of a test. A valid test must be reliable. The first condition for a measurement tool to be considered valid is that it is reliable (Alpar, 2010). The alpha coefficient scale calculated to measure reliability states that if 0.40 to 0.60 it is "low reliable", if 0.60 to 0.80 it is "highly reliable" and if 0.80 to 1.00 it is "highly reliable". When we examine the reliability of substances,

\section{NUTRIENTS}

1. A high carbohydrate diet reduces the destruction of protein in the body.

2. After eating, drinking tea prevents iron intake from foods.

3. Spinach and chard plants are essential for our bodies in terms of iron supply.
4. The increase in the amount of vitamin $\mathrm{C}$ in our body prevents iron absorption.

5. The amount of protein in a glass of whole milk is greater than the amount of protein in a glass of skimmed milk.

6. The amount of calcium in a glass of whole milk is greater than the amount of calcium in a glass of skimmed milk.

7. Calcium is most easily obtained from Yesil leaf vegetables.

8. If a person wants to lose weight, they should choose to eat boiled potatoes instead of eating french fries.

As a result of the analysis carried out on the data, a reliability value of the scale's internal consistency cronbach alpha coefficient as low as $\alpha=0.414$ was obtained.

\section{LIQUID SUBSTANCES}

1. A fluid loss of $2 \%$ of our body weight lowers our performance by $20 \%$.

2. Weighing players before and after competitions is a good way to determine the fluid requirement of individuals.

3. The best time for an athlete to perform fluid intake during exercise is when he or she is thirsty.

4. Fruit juice should be consumed during training and between competitions. 

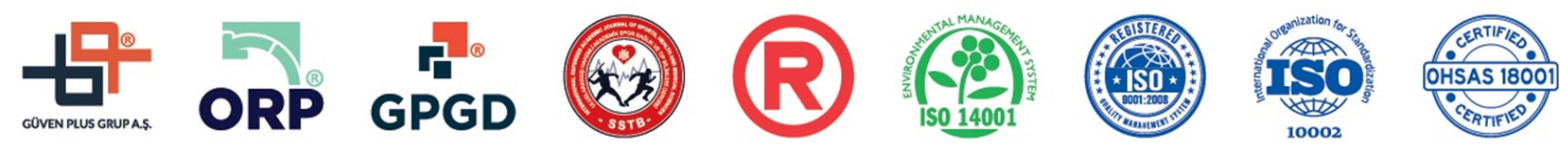

SSTB

www.sstbdergisi.com

International Refereed Academic Journal of Sports, Health and Medical Sciences

January - February - March Issue: 34 Winter Semester Year: 2020

Uluslararası Hakemli Akademik Spor Sağlık ve Tıp Bilimleri Dergisi

Ocak - Şubat - Mart Sayı: 34 Kış Dönemi Yıl: 2020

ID:475 K:459

ISSN Print: 2146-8508 Online 2147-1711

(ISO 18001-OH-0090-13001706 / ISO 14001-EM-0090-13001706 / ISO 9001-QM-0090-13001706 / ISO 10002-CM-0090-13001706)

(TRADEMARK)

(2015/04315- 2015-GE-18972)

5. Energy drinks such as" Monster "and" Red Bull " should be consumed 30 minutes before training.

As a result of the analysis carried out on the data, a reliability value of the scale's internal consistency cronbach alpha coefficient as low as $\alpha=0.067$ was obtained.

\section{WEIGHT GAIN and WEIGHT LOSS}

1. To increase lean muscle mass, it is necessary to eat protein-weighted novelties.

2. It is necessary to use protein powder to increase lean novelties.

3. If an athlete continues his / her training program without ever changing and drinks 6 cups of juice in addition to his / her normal diet, he / she is likely to gain weight.

4. Instead of 1 teaspoon of margarine on the sandwich bread 1 teaspoon of butter should apply.

5. He should eat more cheddar cheese instead of lean mozzarella cheese.

6. He should eat a small amount of salami and a lot of chicken breasts.

7. He should not eat pasta and rice after 17: 00 in the evening.
8. To get more protein, he should eat muesli bars and dried fruit instead of eating yogurt.

As a result of the analysis carried out on the data, a reliability value of the scale's internal consistency cronbach alpha coefficient as low as $\alpha=0.155$ was obtained.

\section{FOOD SUPPLEMENTS}

1. Creatine supplements are very beneficial for athletes who want to get their strength up to the top.

2. The effect of creatine use is quite effective when the body's energy stores are depleted.

3. Creatine has a performance-enhancing effect, as well as a fat increase in body metabolism.

4. Creatine is very useful for improving performance in endurance exercises.

5. Multivitamin tablets should be used by athletes.

6. Athletes should use the iron tablet when they feel too tired and exhausted.

7. Vitamin C promoters should be used regularly by athletes.

8. Vitamin B should be used when energy drop is felt. 

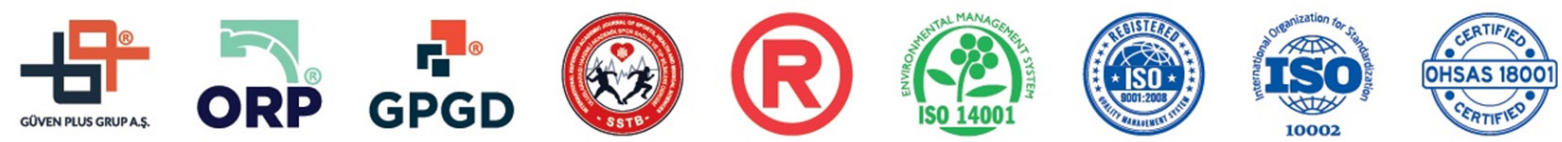

www.sstbdergisi.com

International Refereed Academic Journal of Sports, Health and Medical Sciences

January - February - March Issue: 34 Winter Semester Year: 2020

Uluslararası Hakemli Akademik Spor Sağlık ve Tıp Bilimleri Dergisi

Ocak - Şubat - Mart Sayı: 34 Kıș Dönemi Yıı: 2020 ID:475 K:459

ISSN Print: 2146-8508 Online 2147-1711

(ISO 18001-OH-0090-13001706 / ISO 14001-EM-0090-13001706 / ISO 9001-QM-0090-13001706 / ISO 10002-CM-0090-13001706) (TRADEMARK)

(2015/04315- 2015-GE-18972)

Ninth Protein powder helps to burn fat in the body during exercise.

10. Salt tablets should be used by athletes to prevent cramps that may occur during exercise.

11. The athlete should use thermogenic tablets (L-carnitin) if the goal is to lose weight.

As a result of the analysis carried out on the data, a reliability value of the scale's internal consistency cronbach alpha coefficient as low as $\alpha=0.417$ was obtained.

\section{TEST of NORMALITY}

Normality analysis has been performed to measure whether our data is normally distributed. Normality analysis was studied with Kolmogorov-Smirnov test statistic. Since nutrients $(\mathrm{p}=0.077)$ are all substances ( $p=0.098$ ), our data is normally distributed. It is not normally distributed for other scoring (Total Food, Liquids, Recovery, Weight Control, Food Sup.).

Table 2. Normality Test

\begin{tabular}{|l|rrrr}
\hline & \multicolumn{3}{|c}{ Kolmogorov-Smirnov $^{\mathrm{a}}$} \\
\cline { 2 - 5 } & Statistics & $\mathrm{df}$ & Sig. & $\mathbf{0 7 7}$ \\
\# Food &, 113 & 55 & &, 001 \\
\# Liquids &, 159 & 55 &, 001 \\
\# Replenishment &, 186 & 55 &, 004 \\
\# Weight Control &, 148 & 55 &, 013 \\
\# Food Suplement &, 136 & 55 & $\mathbf{0 9 8}$ \\
Cumulative &, 109 & 55 & &
\end{tabular}



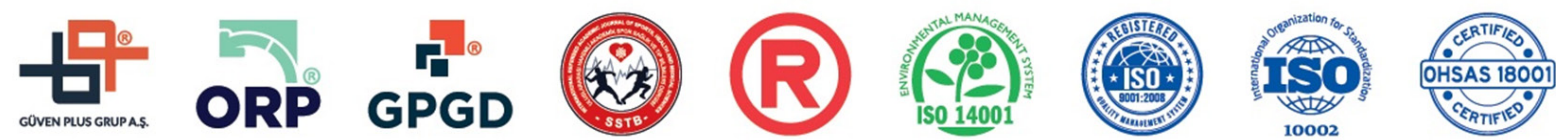

SSTB

www.sstbdergisi.com

International Refereed Academic Journal of Sports, Health and Medical Sciences

January - February - March Issue: 34 Winter Semester Year: 2020

Uluslararası Hakemli Akademik Spor Sağlık ve Tıp Bilimleri Dergisi

Ocak - Şubat - Mart Sayı: 34 Kış Dönemi Yıl: 2020

ID:475 K:459

ISSN Print: 2146-8508 Online 2147-1711

(ISO 18001-OH-0090-13001706 / ISO 14001-EM-0090-13001706 / ISO 9001-QM-0090-13001706 / ISO 10002-CM-0090-13001706) (TRADEMARK)

(2015/04315- 2015-GE-18972)

Table 3. Skewness and flattness values (Descriptive Statistics)

\begin{tabular}{|l|r|r|r|r|}
\hline \multirow{2}{*}{} & \multicolumn{2}{|c|}{ Skewness } & \multicolumn{2}{c|}{ Kurtosis } \\
\cline { 2 - 5 } & Statistic & Std. Error & Statistic & Std. Error \\
\hline \# Food Ingredients &,- 102 &, 322 &, 319 &, 634 \\
\# Liquids &,- 128 &, 322 &,- 739 &, 634 \\
\# Replenishment &, 681 &, 322 &, 224 &, 634 \\
\# Weight Control &, 780 &, 322 &,- 214 &, 634 \\
\# Food Suplements &, 406 &, 322 &, 674 &, 634 \\
Cumulative &, 983 &, 322 & 2,438 &, 634 \\
Valid N (listwise) & & & & \\
\hline
\end{tabular}

\section{EVALUATION of FINDINGS}

Table 4. Percentage of Right, Wrong, Undecided and Unanswered Percentage of Respondents Given to Survey Questions

\begin{tabular}{|l|c|c|c|c|}
\hline \multirow{2}{*}{} & \multicolumn{3}{c|}{$\%$ Percentage } \\
\cline { 2 - 5 } & True & Wrong & Unstable & No Answer \\
\hline Food Ingredients & $\% 48,5$ & $\% 11,5$ & $\% 38,2$ & $\% 1,8$ \\
\hline Liquids & $\% 37,2$ & $\% 9,1$ & $\% 53,5$ & $\% 0,2$ \\
\hline Replenishment & $\% 25,1$ & $\% 0,8$ & $\% 32,4$ & $\% 41,7$ \\
\hline Weight Control & $\% 31,5$ & $\% 8,1$ & $\% 36,5$ & $\% 23,9$ \\
\hline Food Suplement & $\% 37,9$ & $\% 19,0$ & $\% 42,5$ & $\% 0,6$ \\
\hline
\end{tabular}


SSTB

www.sstbdergisi.com

International Refereed Academic Journal of Sports, Health and Medical Sciences

January - February - March Issue: 34 Winter Semester Year: 2020

Uluslararası Hakemli Akademik Spor Sağlık ve Tıp Bilimleri Dergisi Ocak - Şubat - Mart Sayı: 34 Kış Dönemi Yıl: 2020 ID:475 K:459

ISSN Print: 2146-8508 Online 2147-1711

(ISO 18001-OH-0090-13001706 / ISO 14001-EM-0090-13001706 / ISO 9001-QM-0090-13001706 / ISO 10002-CM-0090-13001706) (TRADEMARK)

(2015/04315- 2015-GE-18972)

Table 5. Graphical Representation of the Percentage of Right, Wrong, Undecided and

Unanswered Percentage Given by the Participants to the Survey Questions

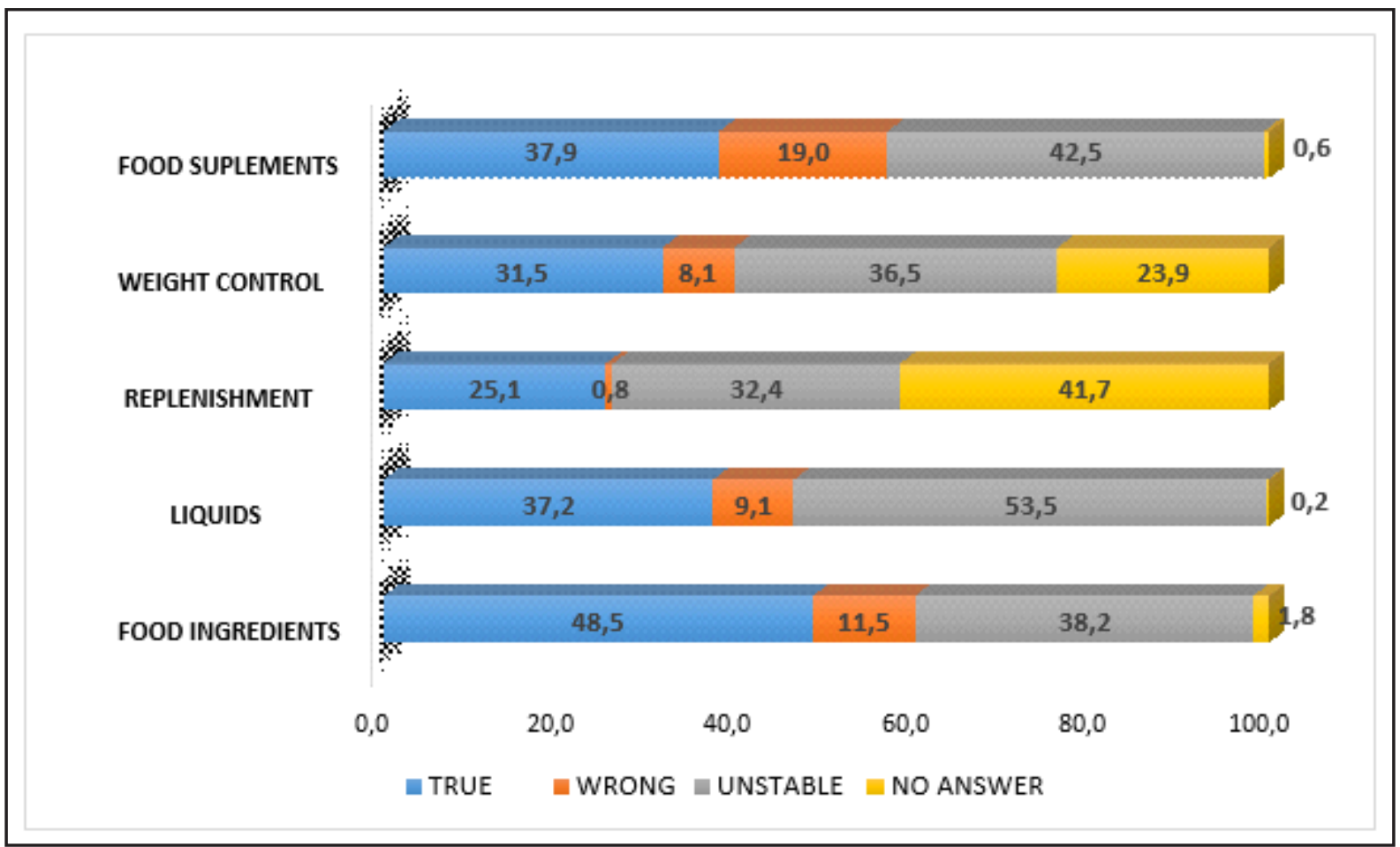

Table 6. Mean Percentages and Standard Deviations of the Questions That the Participants Gave Right, Wrong, Undecided and Unanswered Questions

\begin{tabular}{|l|c|c|c|c|}
\hline \multirow{2}{*}{} & \multicolumn{4}{|c|}{ AVERAGE - STANDARD DEVIATION } \\
\cline { 2 - 5 } & TRUE & WRONG & UNSTABLE & NO ANSWER \\
\hline Food Ingredients & $20,4 \pm 5,1$ & $4,8 \pm 5,4$ & $16 \pm 4,3$ & $0,7 \pm 1,1$ \\
\hline Liquids & $3,3 \pm 1,5$ & $0,8 \pm 1,2$ & $4,8 \pm 1,7$ & - \\
\hline Replenishment & $2,8 \pm 1,7$ & $0,1 \pm 0,4$ & $3,6 \pm 1,8$ & $4,6 \pm 2,1$ \\
\hline Weight Control & $4,7 \pm 2,5$ & $1,2 \pm 1,5$ & $5,5 \pm 2,2$ & $3,6 \pm 2,1$ \\
\hline Food Suplements & $4,2 \pm 2,1$ & $2,1 \pm 2,8$ & $4,7 \pm 2,4$ & $0,1 \pm 0,3$ \\
\hline
\end{tabular}



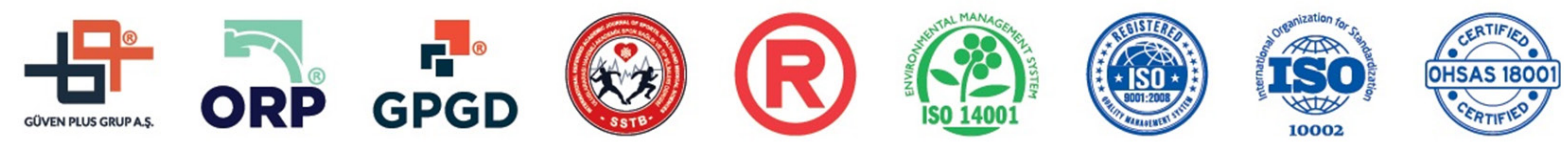

SSTB

www.sstbdergisi.com

International Refereed Academic Journal of Sports, Health and Medical Sciences

January - February - March Issue: 34 Winter Semester Year: 2020

Uluslararası Hakemli Akademik Spor Sağlık ve Tıp Bilimleri Dergisi

Ocak - Şubat - Mart Sayı: 34 Kış Dönemi Yıl: 2020 ID:475 K:459

ISSN Print: 2146-8508 Online 2147-1711

(ISO 18001-OH-0090-13001706 / ISO 14001-EM-0090-13001706 / ISO 9001-QM-0090-13001706 / ISO 10002-CM-0090-13001706) (TRADEMARK)

(2015/04315- 2015-GE-18972)

Analysis on the basis of variables according to sex (nutrients, liquids, refreshments, weight control, food supplements, all variables) :

Since the data is normally distributed (as can be understood from the normality test table, TOPBM and TOTALLAM $\mathrm{p}>0.05$ ), Independent $t$ test was performed. The Independent $t$ test for independent groups is a statistical analysis method used to test whether the averages belonging to the two groups are different from each other. The Independent $t$ test examined whether there was a difference between sex and variables (nutrients and all variables).

$\mathrm{H} 0$ : there is no difference between gender and variables (nutrients, liquids, replenishment, weight control, food supplements, all variables).

$\mathrm{H} 1$ : there is a difference between gender and variables (nutrients, liquids, replenishment, weight control, food supplements, all variables).

Table 7. Descriptive Statistical Table About Gender

\begin{tabular}{|c|c|c|c|c|c|}
\hline & GENDER & $\mathrm{N}$ & Mean & Standard & Standard \\
\hline & & & & Deviation & Error Mean. \\
\hline \multirow[t]{2}{*}{ \# FOOD ING. } & WOMAN & 11 & 17,27 & 5,042 & 1,52 \\
\hline & MAN & 44 & 21,02 & 5,065 & 0,764 \\
\hline \multirow[t]{2}{*}{ CUMULATIVE } & WOMAN & 11 & 30,73 & 5,424 & 1,635 \\
\hline & MAN & 44 & 36,77 & 8,277 & 1,248 \\
\hline
\end{tabular}



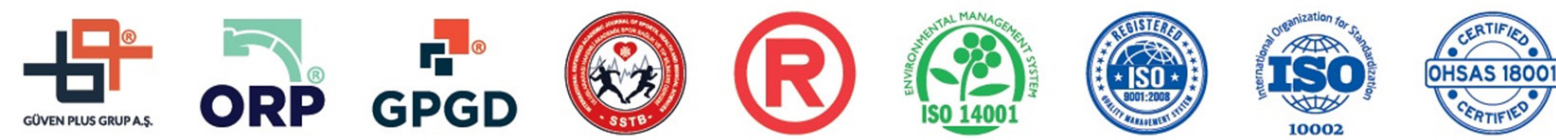

www.sstbdergisi.com

International Refereed Academic Journal of Sports, Health and Medical Sciences

January - February - March Issue: 34 Winter Semester Year: 2020

Uluslararası Hakemli Akademik Spor Sağlık ve Tıp Bilimleri Dergisi Ocak - Şubat - Mart Sayı: 34 Kıș Dönemi Yıı: 2020 ID:475 K:459

ISSN Print: 2146-8508 Online 2147-1711

(ISO 18001-OH-0090-13001706 / ISO 14001-EM-0090-13001706 / ISO 9001-QM-0090-13001706 / ISO 10002-CM-0090-13001706) (TRADEMARK)

(2015/04315- 2015-GE-18972)

Table 8. Homogeneity Test of Variances

\begin{tabular}{|c|c|c|c|c|c|c|c|c|c|}
\hline & \multicolumn{2}{|c|}{ Levene's Test } & \multicolumn{7}{|c|}{ t-test } \\
\hline & \multirow[b]{2}{*}{$\mathrm{F}$} & \multirow[b]{2}{*}{ Sig. } & \multirow[b]{2}{*}{$\mathrm{t}$} & \multirow[b]{2}{*}{$\mathrm{df}$} & \multirow[b]{2}{*}{ Sig. (2-tailed) } & \multirow{2}{*}{$\begin{array}{c}\text { Average } \\
\text { Differences }\end{array}$} & \multirow{2}{*}{$\begin{array}{c}\text { Standard Error } \\
\text { Differences }\end{array}$} & \multicolumn{2}{|c|}{ 95\% Confidence Int. } \\
\hline & & & & & & & & Lower & Upper \\
\hline $\begin{array}{r}\text { \#FOOD Varians } \\
\text { equal }\end{array}$ &, 061 &, 806 & $-2,198$ & 53 & ,032 & $-3,750$ & 1,706 & $-7,171$ &,- 329 \\
\hline Varians not equal & & & $-2,204$ & 15,453 &, 043 & $-3,750$ & 1,701 & $-7,367$ &,- 133 \\
\hline CUM. Varians equal & 1,188 &, 281 & $-2,294$ & 53 &, 026 & $-6,045$ & 2,636 & $-11,332$ &,- 759 \\
\hline Varians not equal & & & $-2,939$ & 23,204 &, 007 & $-6,045$ & 2,057 & $-10,299$ & $-1,792$ \\
\hline
\end{tabular}

The first table is the descriptive statistics table. In other words, it is the table that shows how many people are in which group and the mean and standard deviation of each group. The average for nutrients was 17.27 for girls and 21.02 for boys.

The F value in the first part of the Independent $\mathrm{t}$ test table is used to test whether the variances are homogeneous(Levene test). Right next to you, Sig. if the value is less than 0.05 , the variance is not homogeneous $(\mathrm{p}=0.806$; $\mathrm{p}=0.281$ ). Sig next to $\mathrm{f}$. if the value is greater than 0.05 , it is decided that the variances are homogeneous. Women and men were found to be different between Sex and nutrients and all ingredients after the Independent $t$ test for comparison of Nutritional Information levels. So the H0 hypothesis has been rejected $(\mathrm{t}=-2.198$ for nutrients $; \mathrm{p}=0.032<0.05-\mathrm{t}=$ -2.294 for all ingredients ; $\mathrm{p}=0.026<0.05$ ). When looking at average values it can be said that boys are more than girls. Since other variables(liquids, replenishment, weight control, food supplements) were not normally distributed, the Mann Whitney U test was used. According to the results of the test, $p$ values are greater than 0.05 and it was found that there was no difference between sex and liquid substances, renewal, weight control and food supplements. 


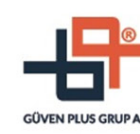

SSTB

www.sstbdergisi.com

International Refereed Academic Journal of Sports, Health and Medical Sciences

January - February - March Issue: 34 Winter Semester Year: 2020

Uluslararası Hakemli Akademik Spor Sağlık ve Tıp Bilimleri Dergisi

Ocak - Şubat - Mart Sayı: 34 Kış Dönemi Yıl: 2020 ID:475 K:459

ISSN Print: 2146-8508 Online 2147-1711

(ISO 18001-OH-0090-13001706 / ISO 14001-EM-0090-13001706 / ISO 9001-QM-0090-13001706 / ISO 10002-CM-0090-13001706) (TRADEMARK)

(2015/04315- 2015-GE-18972)

Table 9. Mann Whitney U Test (Hypothesis Test Summary)

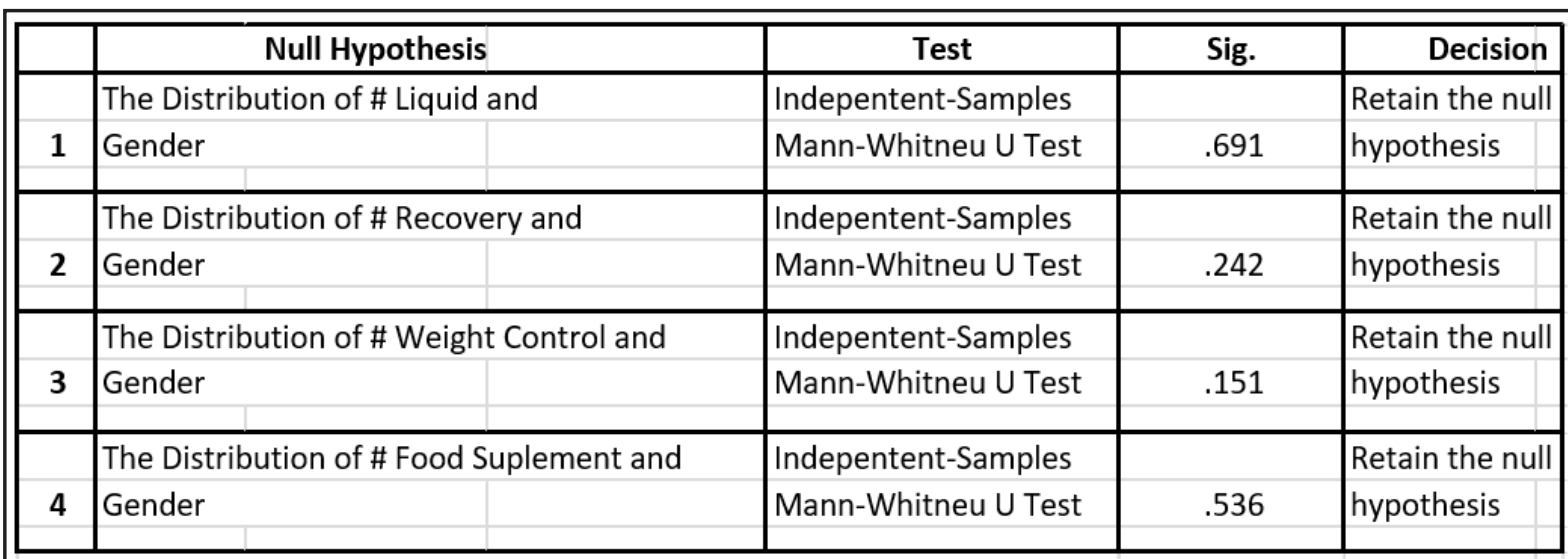

Asymptotic significances are displayed. The significance level is ,05

Variables (nutrients, liquids, regeneration, weight control, food supplements, all variables) analysis by income status:

Table 10. ANOVA Income Test

\begin{tabular}{|l|c|c|c|}
\hline & Number & $\%$ & Cumulativ \% \\
\hline 2000 and Lower & 16 & 29,1 & 29,1 \\
$2001-3000$ & 16 & 29,1 & 58,2 \\
3001 and Upper & 23 & 41,8 & 100,0 \\
Total & 55 & 100,0 & \\
\hline
\end{tabular}

In order to give statistically significant results in the analyses, data of 3000 and above were combined in the case of income.

One-way variance analysis (Anova) is used to calculate the difference between three and more independent averages in a normal distribution data. Anova alone compares the arithmetic averages of three or more groups; when at least one of these comparisons is meaningful, the Anova result is also meaningful. The test investigated whether income states differed according to variables (nutrients, liquids, replenishment, weight control, food supplements, all variables). The homogeneity of the variances was tested with Levene test statistic and ANOVA test statistic was performed. 

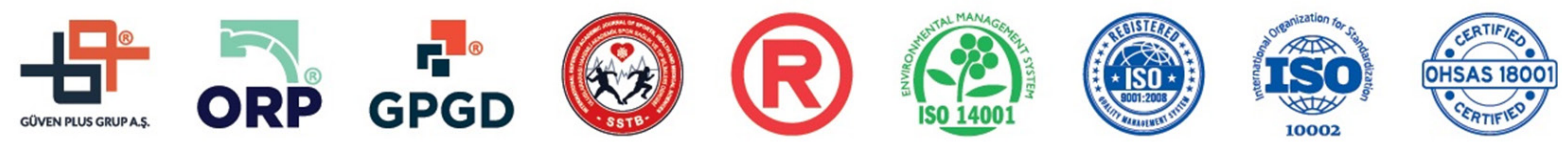

www.sstbdergisi.com

International Refereed Academic Journal of Sports, Health and Medical Sciences

January - February - March Issue: 34 Winter Semester Year: 2020

Uluslararası Hakemli Akademik Spor Sağlık ve Tıp Bilimleri Dergisi Ocak - Şubat - Mart Sayı: 34 Kış Dönemi Yıl: 2020 ID:475 K:459

ISSN Print: 2146-8508 Online 2147-1711

(ISO 18001-OH-0090-13001706 / ISO 14001-EM-0090-13001706 / ISO 9001-QM-0090-13001706 / ISO 10002-CM-0090-13001706) (TRADEMARK)

(2015/04315- 2015-GE-18972)

H0: there is no difference between income states and variables (nutrients, liquids, reple- nishment, weight control, food supplements, all variables).

Table 11. Homogeneity Test of Variances

\begin{tabular}{|l|cccc|}
\hline & Levene Stat. & df1 & df2 & Sig. \\
\hline \# FOOD INGREDIENTS &, 325 & 2 & 52 &, 724 \\
CUMULATIVE & 1,395 & 2 & 52 &, 257 \\
\hline
\end{tabular}

The homogeneity of the variances was tested with the Levene test statistic. since $p>0.05$, the variances are homogeneous.

Table 12. ANOVA

\begin{tabular}{|c|c|c|c|c|c|c|}
\hline & & Total Squares & $\begin{array}{l}\text { Degree of } \\
\text { Freedom }\end{array}$ & Mean & F & Sig. \\
\hline \multirow[t]{3}{*}{ \# FOOD } & Between groups & 28,453 & 2 & 14,226 &, 509 & ,604 \\
\hline & In-group & 1452,457 & 52 & 27,932 & & \\
\hline & Total & 1480,909 & 54 & & & \\
\hline \multirow[t]{3}{*}{ CUMULATIVE } & Between groups & 12,840 & 2 & 6,420 & ,094 & ,910 \\
\hline & In-group & 3548,688 & 52 & 68,244 & & \\
\hline & Total & 3561,527 & 54 & & & \\
\hline
\end{tabular}

There was no difference between income states and variables (nutrients, all variables) according to the ANOVA test statistic. The H0 hypothesis has been accepted $(\mathrm{F}=0.509$ for nutrients; $p=0.604>0.05-F=0.094$ for the sum of all substances; $p=0.910>0.05)$. Post hoc analysis was not performed because there was no difference between income states.

The Kruskal Wallis test was performed because other variables (liquids, replenishment, weight control, food supplements) were not normally distributed. 

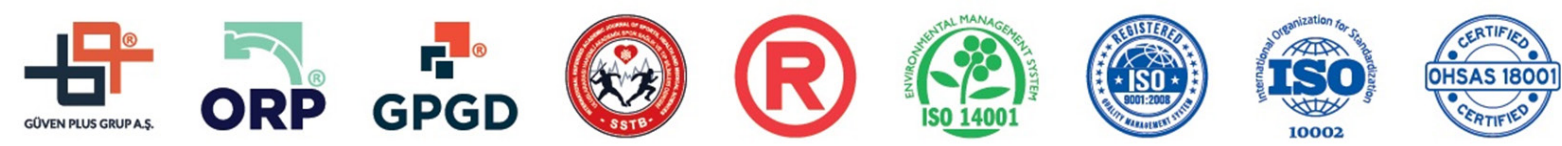

SSTB

www.sstbdergisi.com

International Refereed Academic Journal of Sports, Health and Medical Sciences

January - February - March Issue: 34 Winter Semester Year: 2020

Uluslararası Hakemli Akademik Spor Sağlık ve Tıp Bilimleri Dergisi

Ocak - Şubat - Mart Sayı: 34 Kış Dönemi Yıl: 2020

ID:475 K:459

ISSN Print: 2146-8508 Online 2147-1711

(ISO 18001-OH-0090-13001706 / ISO 14001-EM-0090-13001706 / ISO 9001-QM-0090-13001706 / ISO 10002-CM-0090-13001706)

(TRADEMARK)

(2015/04315- 2015-GE-18972)

Table 13. Kruskal Wallis

\begin{tabular}{|l|cccc|}
\hline & & \multicolumn{3}{c|}{ \# Weight } \\
& \# Liquid & \# Replenishment & Control & \# Food Suplements \\
\hline Chi-Square &, 425 &, 488 &, 004 &, 279 \\
df & 2 & 2 & 2 & 2 \\
Asymp. Sig. & $\mathbf{, 8 0 9}$ & $\mathbf{, 7 8 3}$ & $\mathbf{, 9 9 8}$ &, $\mathbf{8 7 0}$ \\
\hline
\end{tabular}

According to the results of the test, $\mathrm{p}$ values are greater than 0.05 and it was found that there is no difference between income status and liquid substances, renewal, weight control and food supplements.

Analysis on the basis of variables (nutrients, liquids, refreshments, weight control, food supplements, all variables) according to educational status in nutrition:
$\mathrm{H} 0$ : there is no difference between training and variables (nutrients, liquids, replenishment, weight control, food supplements, all variables).

H1: there is a difference between training and variables (nutrients, liquids, replenishment, weight control, food supplements, all variables).

Table 14. Independent t Test

\begin{tabular}{|ll|c|c|c|c|}
\hline & $\begin{array}{l}\text { HAVE YOU EVER } \\
\text { BEEN EDUCATION } \\
\text { ABOUT } \\
\text { NUT RITION? }\end{array}$ & N & Mean & Standard Deviation & Standard Error Average \\
\hline \multirow{2}{*}{ \# FOOD } & YES & 24 & 20,29 & 6,868 & 1,402 \\
& NO & 31 & 20,26 & 3,633 & 0,652 \\
\hline \multirow{2}{*}{ CUM. } & YES & 24 & 36,54 & 10,476 & 2,138 \\
& NO & 31 & 34,81 & 5,764 & 1,035 \\
\hline
\end{tabular}

The F value in the first part of the Independent $t$ test table is used to test whether the variances are homogeneous(Levene test). Right next to you, Sig. if the value is less than 0.05 , the variances are not homogeneous $(p=0.001$; $\mathrm{p}=0.009$ ). After an Independent $t$ test, it was found that there was no difference between nutrients and all ingredients by training. So the $\mathrm{H} 0$ hypothesis has not been rejected (for nutrients $\mathrm{t}=0.022 ; \mathrm{p}=0.983>0.05-$ the sum of all substances $t=0.730 ; p=0.470>0.05$ ). 


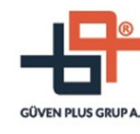

International Refereed Academic Journal of Sports, Health and Medical Sciences

January - February - March Issue: 34 Winter Semester Year: 2020

Uluslararası Hakemli Akademik Spor Sağlık ve Tıp Bilimleri Dergisi

Ocak - Şubat - Mart Sayı: 34 Kıș Dönemi Yıl: 2020 ID:475 K:459

ISSN Print: 2146-8508 Online 2147-1711

(ISO 18001-OH-0090-13001706 / ISO 14001-EM-0090-13001706 / ISO 9001-QM-0090-13001706 / ISO 10002-CM-0090-13001706) (TRADEMARK)

(2015/04315- 2015-GE-18972)

Since other variables (liquids, replenishment, weight control, food supplements) were not normally distributed, the Mann Whitney U test was performed.

Table 16. Mann Whitney U test (Hypothesis Test Summary)

\begin{tabular}{|c|c|c|c|c|}
\hline & Null Hypo & Test & Sig. & Decision \\
\hline & The Distribution of $\neq$ & Indepentent-Samples & & Retain the null \\
\hline \multirow[t]{2}{*}{1} & Nutrition Question & Mann-Whitneu U Test & 671 & hypothesis \\
\hline & The Distribution of \# Recovery and & Indepentent-Samples & & Retain the null \\
\hline \multirow[t]{2}{*}{2} & Nutrition Question & Mann-Whitneu U Test & .197 & hypothesis \\
\hline & The Distribution of \# Weight Control and & Indepentent-Samples & & Retain the null \\
\hline \multirow[t]{2}{*}{3} & Nutrition Question & Mann-Whitneu UTest & .514 & hypothesis \\
\hline & The Distribution of \# Liquid and & Indepentent-Samples & & Retain the null \\
\hline 4 & Nutrition Question & Mann-Whitneu UTest & .085 & hypothesis \\
\hline \multicolumn{4}{|c|}{ totic significances are displayed. The signi } & \\
\hline
\end{tabular}

According to the results of the test, $\mathrm{p}$ values are greater than 0.05 and it was found that there was no difference between nutrition education and liquid substances, renewal, weight control and food supplements.

\section{DISCUSSION and CONCLUSION}

The main objective of this research is to compare nutrition information levels of female and male wrestlers participating in the Interuniversity Wrestling Championship held in Sivas province on April 25-30, 2017, and to examine the effect of income level and nutrition education on nutrition information levels of wrestlers.

According to the results of the research, it is understood that income status is not related to nutritional information level. It was revealed that there was a difference between sex and nutrients and all ingredients (thought to be more common in men), there was no difference between liquids, refreshments, weight control, and food supplements. With training on nutrition, it was found that nutrients are not different from liquid ingredients, refreshment, weight control, food supplements, and not all ingredients.

As a result of research (Gümüşdağ and Kartal; 2019), it was determined that judoists had sufficient knowledge about nutrition. However, the level of nutrition knowledge can be further increased by directing athletes to nutrition training. Referees are seen to be affected by ads in preference to vitamins, whi- 


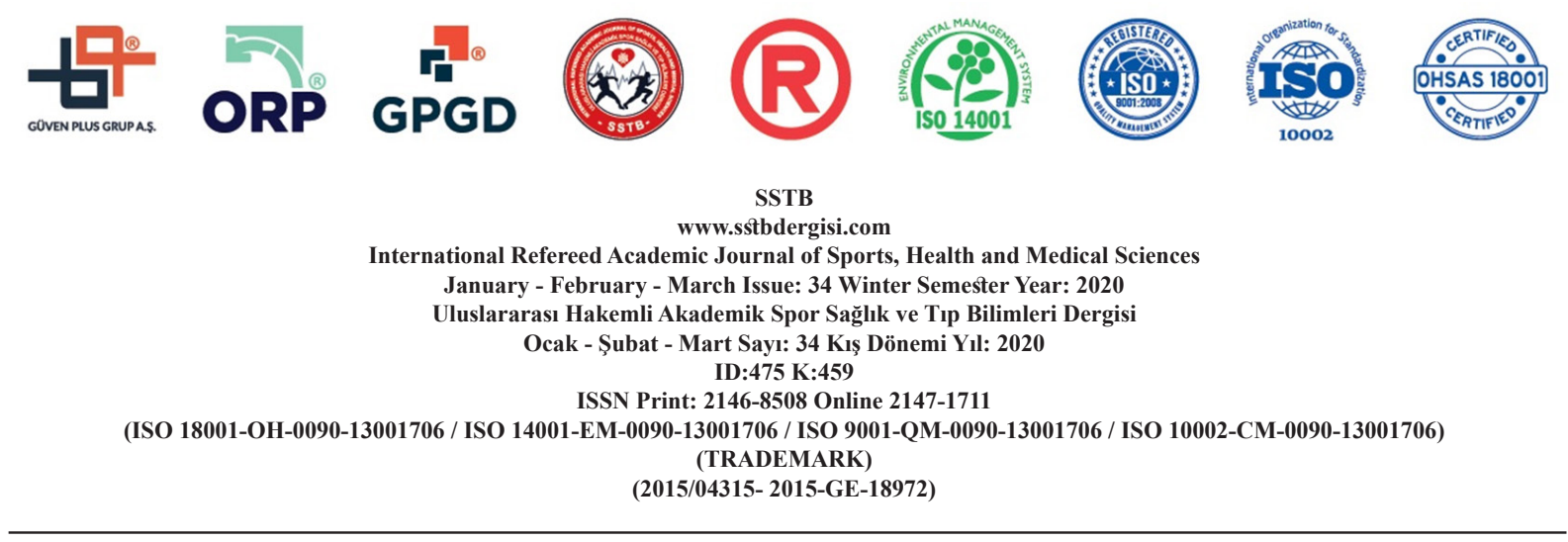

le some people sometimes take ads into account. The majority of people are safe about the reliability of the illegally sold vitamins it seems that they are not, and 19.we can show the substance as evidence for that substance. In line with these results determined within the scope of the research, it was concluded that the vast majority of football referees do not use vitamins. But some referees seem to use vitamins. It is also observed that the sensitivity of referees on health-related issues is similar in all quarters. The referees think that they have sufficient knowledge about vitamins and act in favour of vitamin use in case of health problems. (Gümüşdağ and Kartal; 2019).

As a result, it is thought that it will be useful to inform wrestlers who are trained at the university about their nutritional knowledge, which significantly affects performance and success. Research has shown that a significant proportion of athletes do not have sufficient knowledge of athlete nutrition, and some are erroneous found to have eating habits, family and coaches active in the training of athletes they were determined to be. It was therefore concluded that it would be beneficial for athletes and their families and coaches to be informed about athlete nutrition.

\section{REFERENCES}

AVCIOĞULLARI, C., (1993). İstanbul Güreş İhtisas Klubü Koruma Vakfı Yayını Tezler Dizisi, İstanbul

DEMIRCI, N., (1995). A'dan Z'ye Spor. Ankara: Neyir yayıncılık ve matbaacılık

GÖKDEMİR, K., (2000). Güreş Antrenmanının Bilimsel Temelleri. Ankara: Poyraz ofset

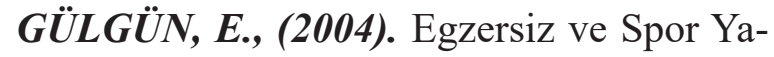
panlar için Beslenme. Nobel yayınları, 3. Bask1, Ankara

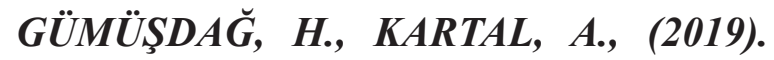
Examination OfVitamin Usage Habits Of Football Referees. The Online Journal of Recreation and Sport (TOJRAS), Volume 8, İssue 3, July 2019. doi.org/10.22282/ ojrs.2019.53

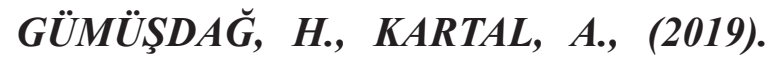

Measurement And Comparison Nutrit1on Knowledge Level Of Judo Athletes. Uluslararası Hakemli Akademik Spor Sağlık ve Tıp Bilimleri Dergisi, Sayı: 33, 2019. Doi: 10.17363/SSTB.2019.33.1

GÜNEŞ, Z., (2009). Spor ve Beslenme. 5. Baskı, Nobel Yayın Dağıtım, Ankara

GÜNEŞ, Z., ERSOY, G., (1997). SESAM Beslenme Ünitesine Müracaat Eden Elit Düzey Sporcuların Beslenme Alışkanlık- 
International Refereed Academic Journal of Sports, Health and Medical Sciences

January - February - March Issue: 34 Winter Semester Year: 2020

Uluslararası Hakemli Akademik Spor Sağlık ve Tıp Bilimleri Dergisi

Ocak - Şubat - Mart Sayı: 34 Kış Dönemi Yıl: 2020 ID:475 K:459

ISSN Print: 2146-8508 Online 2147-1711

(ISO 18001-OH-0090-13001706 / ISO 14001-EM-0090-13001706 / ISO 9001-QM-0090-13001706 / ISO 10002-CM-0090-13001706) (TRADEMARK)

(2015/04315- 2015-GE-18972)

ları, Kan Biyokimya Bulguları ve fiziksel Özelliklerinin Spor Branşlarına Yönelik Değerlendirilmesi. Beslenme ve Diyet Der. Cilt 26 (2), 13- i 8, 1997

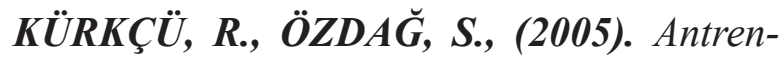
man Bilimi Işı̆̆̆ında Güreş. Ankara: Saray Kağıtçılık ve Matbaacılık

ŞAHIN, H.M., (2005). Beden Eğitimi ve Spor Sözlüğü. Morpa Kültür Yayınları, İstanbul.

ŞANLIER, N., KONAKLIOĞLU, E., GÜÇER, E., (2009). Gençlerin Beslenme Bilgi alışkanlıkları ile Beden Kütle İndeksleri Arasındaki iliki, G.Ü. Gazi Eğitim Fakültesi Dergisi, Cilt 29, Sayı 2, 333-352
ŞEMŞEK, Ö., YÜKTAŞIR, B., ŞEMŞEK, S., (2001). "Ergojenik Yardımcı Olarak Kullanılan Besin Suplementleri”, Atatürk Üniversitesi Beden Eğitimi ve Spor Bilimleri Dergisi, Vol:1, Sayı:3, s.74-81, Erzurum

TANRIVERDİ, D., SAVAŞ, E., GÖNÜLLÜOĞLI, N., KURDAL, E., BALIK, G., (2011). Lise öğrencilerinin yeme tutumları, yeme davranışları ve benlik saygılarının incelenmesi, Gaziantep Tip Dergisi, 17(1), 33-39

ZORBA, E., (2001). Fiziksel Uygunluk. Gazi Kitabevi, Ankara 